\title{
Ammonium Removal from Ammonium Rich Solution by Bio Char
}

\author{
Harada Hiroyuki* ${ }^{\circledR}$, Akagi Kotaro, Endar Hidayat \\ Department of Environmental Science, Prefectural University of Hiroshima, Shobara, Hiroshima, Japan \\ Email: ^ho-harada@pu-hiroshima.ac.jp
}

How to cite this paper: Hiroyuki, $\mathrm{H}$., Kotaro, A. and Hidayat, E. (2022) Ammonium Removal from Ammonium Rich Solution by Bio Char. Journal of Environmental Protection, 13, 171-182.

https://doi.org/10.4236/jep.2022.131011

Received: December 13, 2021

Accepted: January 21, 2022

Published: January 24, 2022

Copyright $\odot 2022$ by author(s) and Scientific Research Publishing Inc. This work is licensed under the Creative Commons Attribution International License (CC BY 4.0).

http://creativecommons.org/licenses/by/4.0/

\begin{abstract}
When biochar made from waste pallet was added to treated livestock wastewater, the total nitrogen and ammonium ion concentrations decreased, with removal rates over 10 days of about $60 \%$ and $30 \%$, respectively. Bacteria were isolated with high ammonium removal ability and they were identified based on their 16S rRNA gene sequences. Anaerobic denitrifying Cronobacter spp. was isolated from the biochar used for water purification. When each strain was cultured in a liquid medium containing ammonium sulfate (initial ammonium concentration $30 \mathrm{mg} / \mathrm{L}$ ), the highest ammonium removal rates were $83.8 \%-96.5 \%$. Organic acids were more effective than carbohydrates as sole carbon sources for nitrogen removal from wastewater. The absorbance at 660 $\mathrm{nm}$ increased with nitrogen removal, indicating that cells proliferated, so it was presumed that ammonium was taken up by assimilation.
\end{abstract}

\section{Keywords}

Livestock Wastewater, Ammonium Removal Rate, Cronobacter spp., $16 \mathrm{~S}$ rRNA

\section{Introduction}

Livestock wastewater is treated by the activated sludge process and the effluent is discharged into public water areas, but it still contains high nitrogen concentrations and contributes to water pollution. Therefore, nitrogen removal, especially ammonium, is desired prior to effluent discharge. The most common post-treatment of activated sludge-treated wastewater is further nitrification-denitrification treatment (secondary treatment). The investigation of secondary treated wastewater of nine livestock farms nationwide reported that most of the residual nitrogen was ammonium when the $\mathrm{pH}$ after treatment was 8 or higher, whereas nitrate and 
nitrite were detected when the $\mathrm{pH}$ was 8 or less. The nitrogen removal rate when nitrification-denitrification or anammox is introduced as post-treatment can be estimated [1]. The characteristics of bacteria capable of aerobic denitrification by catabolism and assimilation have been reported [2] [3] [4] [5]. In these studies, the ratio of carbon to nitrogen was an important parameter affecting denitrification. However, in secondary treated water, there are few organic substances that can be utilized for assimilation. Therefore, the denitrification function can be confirmed for the microorganisms supported on biochar and when the organic matter derived from biochar is used, it is effective in supporting denitrification under conditions where there is little organic matter.

Biochar is also known for its ability to absorb ammonia, and it has been reported about adsorption capacities that there are $7.0 \mathrm{mg} / \mathrm{g}$ as bamboo, while this improves to $22.2 \mathrm{mg} / \mathrm{g}$ after it is pulverized with a ball mill [6]. Moreover, biochar made from corn cob showed high values of $22.6 \mathrm{mg} / \mathrm{g}$ [7].

To utilize function of ammonia fixing microorganisms is one method to enhance ammonia removal of the biochar. The interaction between the adsorption function of biological charcoal itself and the removal action by microorganisms can be expected. Bacillus subtilis species are mainly utilized when employing the former enhancement of biological treatment function, and this method enables treatment of relatively high concentrations of ammonia [8] [9] [10]. Additionally, charcoal has been reported to support and promote the function of microorganisms [11]. For the latter method, larger surface areas tend to have higher efficiency, but it is about $30 \mathrm{mg} / \mathrm{g}$.

In this study, we investigated the treatment of secondary treated water from livestock wastewater using biochar. Since the ammonia concentration is relatively high, we expected biological treatment by the function of biochar [12].

The ability to remove ammonium was evaluated and confirmed using an ammonium-based artificial waste solution that did not contain a carbon source. Bacteria were isolated with high ammonium removal ability and the characteristics of ammonium removal by assimilation were investigated.

\section{Materials and Methods}

\subsection{Bacterial Strains and Batch Experimental Setup}

The biochar obtained from Takino Filter Inc. contains bacteria. The biochar was made from used wood pallet carbonized at $700^{\circ} \mathrm{C}$. The major pore distribution was from 1.6 to $1.7 \mathrm{~nm}$. Microorganisms and their nutrient sources were impregnated in the charcoal. The charcoal was compression-molded into a cylinder with a diameter of $5 \mathrm{~cm}$, height of $2 \mathrm{~cm}$ and specific surface area of $350 \mathrm{~m}^{2} / \mathrm{g}$ (Figure 1) [13]. The biochar was covered with a commercially available draining net and placed near the middle of a $1 \mathrm{~L}$ beaker. One liter of solution was stirred with a hot stirrer over 8 days at a water temperature of $35^{\circ} \mathrm{C}$ and $400 \mathrm{rpm}$ (Figure 1). Ten milliliters of treated solution were filtered through a membrane filter (pore diameter: $0.45 \mu \mathrm{m}$ ). 


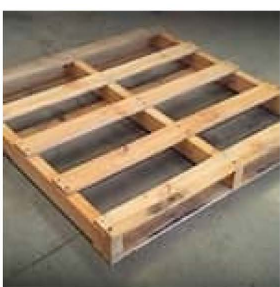

(Material of charcoal) Waste pallet

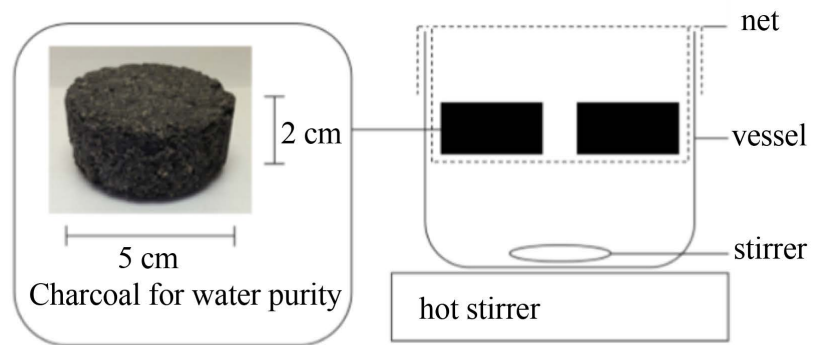

Bio charExperimental setup

$35^{\circ} \mathrm{C}, 400 \mathrm{rpm}$

Figure 1. Batch experimental setup for water purification.

\subsection{Effluent of Treated Livestock Wastewater and Synthetic Wastewater}

\subsubsection{Effluent of Treated Livestock Wastewater}

The secondary treated wastewater was sampled from an agricultural waterway in Kanoya City, Kagoshima Prefecture, Japan. Livestock farming wastewater was treated by activated sludge then discharged into the waterway. When sampled from the waterway, the water was colored (Figure 2).

\subsubsection{Synthetic Water}

Synthetic wastewater was prepared based on Table 1 and Table 2 [14]. The solution in Table 1 did not contain a carbon source and was used in the experiment in which biochar was added. The solution in Table 2 was used to evaluate the ability of the isolated microorganism to remove ammonia. In this case, glucose or sodium acetate was used as the carbon source. To investigate the influence of different carbon sources on ammonium removal, a range carbohydrates and organic acids were tested as sole carbon sources.

All reagents used were commercially available special grades that were obtained from Kanto Chemical Co., Inc.

\subsubsection{Isolation of Microorganisms and Evaluation of Denitrification Ability}

A portion of the synthetic wastewater was sampled and serially diluted with sterile $0.8 \%$ sodium chloride solution before spreading $100 \mu \mathrm{L}$ aliquots onto synthetic wastewater agar plates (Table 1).

The acquired strain was cultured in a bouillon liquid medium for $24 \mathrm{~h}$ by using a shaker at a constant temperature of $35^{\circ} \mathrm{C}$ while shaken at $120 \mathrm{rpm}$. The medium composition was as follows: $1 \mathrm{~g} / \mathrm{L}$ beef extract, $1 \mathrm{~g} / \mathrm{L}$ polypeptone, 0.3 $\mathrm{g} / \mathrm{L} \mathrm{NaCl}$ and $\mathrm{pH}$ adjusted to 7.0. Then, $100 \mu \mathrm{L}$ of the culture solution was added to a conical flask containing the ammonium sulfate-containing medium (Table 2 ), cultured in a shaker at a constant temperature of $35^{\circ} \mathrm{C}$ while shaken at 120 rpm for $24 \mathrm{~h}$.

Ammonium ( $\mathrm{NH}_{4}^{+}$) was measured by the indophenol method, and the $\mathrm{NH}_{4}^{+}$ removal rate was determined by Equation 1 from the $\mathrm{NH}_{4}^{+}$concentration in the solution before and after culturing. In addition, nitrite $\left(\mathrm{NO}_{2}^{-}\right)$and nitrate 


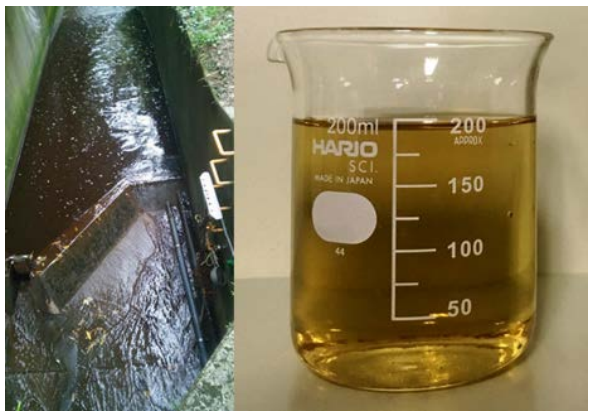

Figure 2. Left: Sample location (water canal) and right: sample appearance.

Table 1. Synthetic waste water medium.

\begin{tabular}{cc}
\hline Reagent & Amount per liter final volume (pH 8) \\
\hline $\mathrm{NH}_{4} \mathrm{Cl}$ & $387 \mathrm{mg}$ \\
$\mathrm{K}_{2} \mathrm{HPO}_{4}$ & $33.3 \mathrm{mg}$ \\
$\mathrm{NaHCO}_{3}$ & $767 \mathrm{mg}$ \\
$\mathrm{MgSO}_{4} \cdot 7 \mathrm{H}_{2} \mathrm{O}$ & $200 \mathrm{mg}$ \\
\hline
\end{tabular}

Table 2. Medium containing ammonium.

\begin{tabular}{cc}
\hline Reagent & Amount per liter final volume $(\mathrm{pH} 8)$ \\
\hline $\left.\mathrm{NH}_{4}\right)_{2} \mathrm{SO}_{4}$ & $100 \mathrm{mg}$ \\
$\mathrm{MgSO}_{4} \cdot 7 \mathrm{H}_{2} \mathrm{O}$ & $50 \mathrm{mg}$ \\
$\mathrm{CaCl}_{2} \cdot 2 \mathrm{H}_{2} \mathrm{O}$ & $20 \mathrm{mg}$ \\
$\mathrm{FeSO}_{4} \cdot 7 \mathrm{H}_{2} \mathrm{O}$ & $1 \mathrm{mg}$ \\
$\mathrm{K}_{2} \mathrm{HPO}_{4}$ & $200 \mathrm{mg}$ \\
D-glucose or $\mathrm{CH}_{3} \mathrm{COONa}$ & $500 \mathrm{mg}$ \\
\hline
\end{tabular}

$\left(\mathrm{NO}_{3}^{-}\right.$) were measured by ion chromatography, and turbidity (optical density (OD) at $660 \mathrm{~nm}$ ) was measured by an ammonium-visible spectrophotometer (wavelength: $660 \mathrm{~nm}$ ) [5].

Total nitrogen (TN) and total organic carbon (TOC) were measured with a TOC meter (Shimadzu: TOC-L), and $\mathrm{pH}$ was measured with a $\mathrm{pH}$ meter (HORIBA: D-52). Color (measured at a wavelength of $390 \mathrm{~nm}$; cobalt method) was measured following the tap water test method [15].

Redox potential was measured with an oxidation-reduction potential (ORP) meter (ORP-Tester 10); before analysis the treated wastewater was filtered through an ADVANTEC membrane filter (pore diameter: $0.45 \mu \mathrm{m}$ ).

$$
\text { Removal rate of } \mathrm{NH}_{4}^{+}(\%) \frac{\text { Initial } \mathrm{NH}_{4}^{+}[\mathrm{mg} / \mathrm{L}]-\mathrm{Final} \mathrm{NH}_{4}^{+}[\mathrm{mg} / \mathrm{L}]}{\text { Initial } \mathrm{NH}_{4}^{+}[\mathrm{mg} / \mathrm{L}]} \times 100
$$

PCR amplification and sequencing of the 16S rRNA genes of two pure colonies isolated from the treated synthetic wastewater was used to identify the 
strains. The amplified 16S rRNA gene sequences were analyzed by BLAST search to identify closely related strains [16] [17]. Table 3 shows the primers used for amplification.

\subsection{Microscopic Observation}

In this experiment, Gram staining was performed with reference to the modified Hucker method [19]. Cells were fixed in methanol for 1 to $2 \mathrm{~min}$, completely dried and then $1 \mathrm{~mL}$ of crystal violet was added and stained for $1 \mathrm{~min}$. Then, the crystal violet on the slide glass other than the fixed part was washed with distilled water, $1 \mathrm{~mL}$ of Lugol's solution was added, and the stain solution was fixed to the cells. Then, after staining with $1 \mathrm{~mL}$ of safranin solution for $1 \mathrm{~min}$, the mixture was washed with distilled water and the excess water was removed. A Nikon ECLIPSE E600 microscope was used for observation.

\subsection{Creation of Cronobacter Growth Curve and Calibration Curve}

The preserved strain of Cronobacter was spread onto fresh bouillon medium and incubated at $35^{\circ} \mathrm{C}$. A single colony from the plate culture was inoculated into $5 \mathrm{~mL}$ of bouillon liquid medium and incubated in a shaker at a constant temperature of $35^{\circ} \mathrm{C}$ while shaken at $120 \mathrm{rpm}$. One milliliter of this primary culture was inoculated into a $500 \mathrm{~mL}$ Erlenmeyer flask containing $250 \mathrm{~mL}$ of liquid bouillon medium and incubated in a shaker at a constant temperature of $35^{\circ} \mathrm{C}$ while shaken at $120 \mathrm{rpm}$.

Aliquots of the culture solution from the Erlenmeyer flask were collected every $3 \mathrm{~h}$ to monitor culture growth. Absorption was measured on an ultraviolet-visible spectrophotometer at $660 \mathrm{~nm}$ and serially diluted with sterile $0.8 \%$ sodium chloride solution. One hundred microliter aliquots of the diluted solutions were spread plated onto bouillon agar plates and incubated at $35^{\circ} \mathrm{C}$. The number of colonies formed was used to determine the colony-forming units (CFU) of viable bacteria $(\mathrm{CFU} / \mathrm{ml})$.

\subsection{Cronobacter Growth and Carbon Source Utilization in Liquid Medium Containing Different Nitrogen Sources}

Cronobacter strains were pre-streaked onto bouillon agar plates and then inoculated into test tubes containing $5 \mathrm{~mL}$ of bouillon liquid medium. The cells were incubated for $24 \mathrm{~h}$ in a shaker while shaken at $120 \mathrm{rpm}$ at a constant temperature of $35^{\circ} \mathrm{C}$. One hundred microliters of this pre-culture was inoculated into ammonium sulfate liquid medium (Table 2) and incubated for $24 \mathrm{~h}$ in a shaker while shaken at $120 \mathrm{rpm}$ at a constant temperature of $35^{\circ} \mathrm{C}$. The carbon sources used

Table 3. Primers used for amplification and sequencing of the 16S rRNA gene [18].

\begin{tabular}{ccccc}
\hline Primer & Sequence (5’-3’) & 16S rRNA & PCR product size (bp) & PCR conditions \\
\hline $357 \mathrm{~F}$ & CCTACGGGAGGCAGCAG & $357-371$ & 581 & $942 \mathrm{~min}{ }^{\oplus} 94^{\circ} \mathrm{C} 30 \mathrm{sec}, 52^{\circ} \mathrm{C} 30 \mathrm{sec}$ \\
937R & CCGTCAATTCCTTTGAGTTT & $918-937$ & & $72^{\circ} \mathrm{C} 1 \mathrm{~min} \times 30 \mathrm{cycles}^{\oplus} 72^{\circ} \mathrm{C} 10 \mathrm{~min}$ \\
\hline
\end{tabular}


were sugars D-glucose, fructose, galactose, xylose, maltose, and sucrose; and organic acids citric acid, succinic acid, acetic acid, lactic acid, malic acid, and sodium acetate. The culture solution was filtered with a $0.45 \mu \mathrm{m}$ membrane filter prior to analysis.

\section{Results}

\subsection{Raw Effluent Treatment}

The raw wastewater contained mean values of TOC and TN of 43.6 and 115.9 $\mathrm{mg} / \mathrm{L}$, respectively, with color and $\mathrm{pH}$ of 493 and 6.39 , respectively $(\mathrm{n}=3)$. Of the total TN, 98\% was present as ammonia nitrogen. This result was based on the release of wastewater from the livestock farm into the waterway and dilution by the natural water flow.

The effect of charcoal was determined by monitoring the changes in TN and color when charcoal was added to the livestock wastewater and incubated for 10 days (Figure 3). The TN decreased from an initial concentration of $115.9 \mathrm{mg} / \mathrm{L}$ to $26.2 \mathrm{mg} / \mathrm{L}$ and the color decreased from 493 to 324 after 10 days. The charcoal treatment removed approximately $77.4 \%$ of TN from raw effluent. In this experiment, it was suspected that a biofilm was formed by microorganisms adhering to the surface of biological charcoal, and an aerobic layer was formed on the surface of the biofilm (Figure 4). Ammonium was mainly removed by assimilation into cells [20].

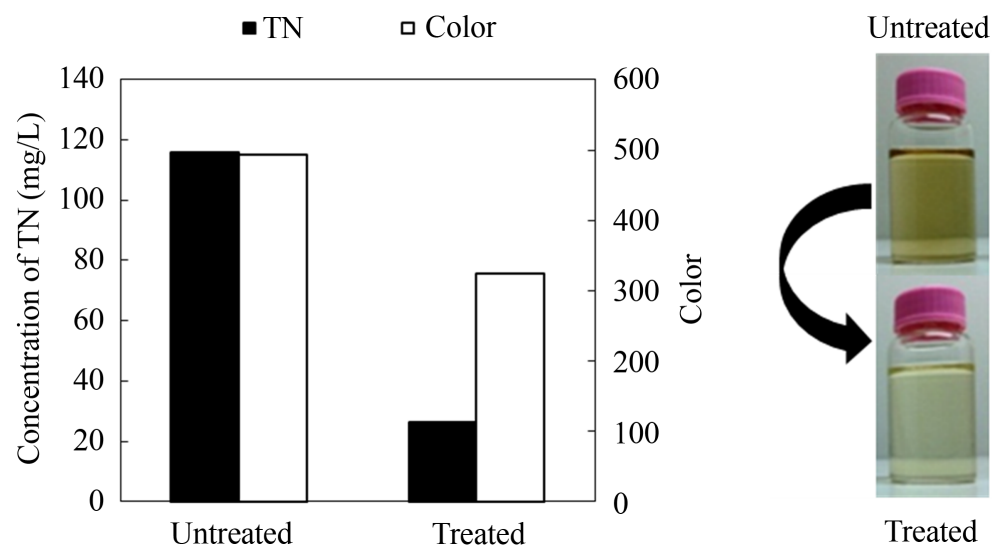

Figure 3. Changes in total nitrogen (TN) and chromaticity before and after treatment.

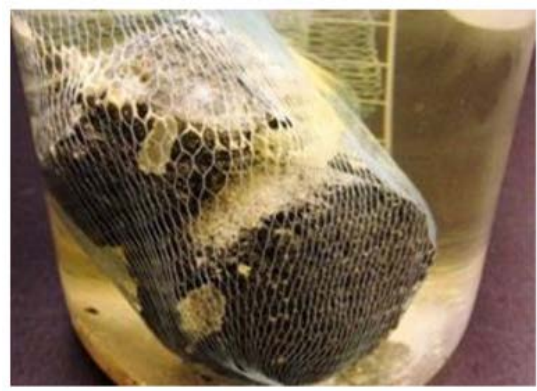

Figure 4. Biofilm fouling. 


\subsection{Synthetic Wastewater}

When biological charcoal was added to the synthetic wastewater and incubated for 20 days, the diurnal changes in $\mathrm{NH}_{4}^{+}, \mathrm{NO}_{2}^{-}+\mathrm{NO}_{3}^{-}$, ORP and TOC were monitored (Figure 5).

The $\mathrm{NH}_{4}^{+}$concentration decreased from $112 \pm 4 \mathrm{mg} / \mathrm{L}$ to $46.2 \mathrm{mg} / \mathrm{L}$ by day 8 , showing that approximately $60 \%$ of $\mathrm{NH}_{4}^{+}$could be removed by biological charcoal treatment over 8 days. Because the initial pH of 8.02 showed little change to $\mathrm{pH} 8.34 \pm 0.26$ during the treatment period, it was considered that there was almost no effect of $\mathrm{NH}_{4}^{+}$stripping that occurs under basic conditions of $\mathrm{pH} 9$ or higher in synthetic wastewater [14]. In addition, low or non-detectable concentrations of $\mathrm{NO}_{2}^{-}(0 \mathrm{mg} / \mathrm{L})$ and $\mathrm{NO}_{3}^{-}(0.13 \pm 0.05 \mathrm{mg} / \mathrm{L})$ were detected in the wastewater.

The ammonium concentration during ammonium utilization regulates ammonium assimilation, which results in improved aerobic denitrification efficiency [21].

The TOC hardly decreased and stayed between 243 and $298 \mathrm{mg} / \mathrm{L}$ after the second day, and ORP maintained anaerobic conditions from $-53.5 \mathrm{mV}$ to -70.5 $\mathrm{mV}$.

A biofilm was formed on the surface of biological charcoal and it was considered that the bacteria within the biofilm secreted extracellular polysaccharides [21].

Because the detected $\mathrm{NO}_{3}^{-}$concentration was relatively lower than the decrease in $\mathrm{NH}_{4}^{+}$, it was considered that the decrease in $\mathrm{TN}$ was taken up by anabolic action. Kim et al. reported that a decrease in $\mathrm{NH}_{4}^{+}$concentration and accompanying cell production by bacterial isolates occurred under conditions of $30 \%$ dissolved oxygen and carbon: nitrogen ratio of 8 [3]. In this study, the carbon: nitrogen ratio $=0.37$ for actual wastewater and 2.67 for artificial wastewater. In this study, carbon sources were considered to be supplied from charcoal.
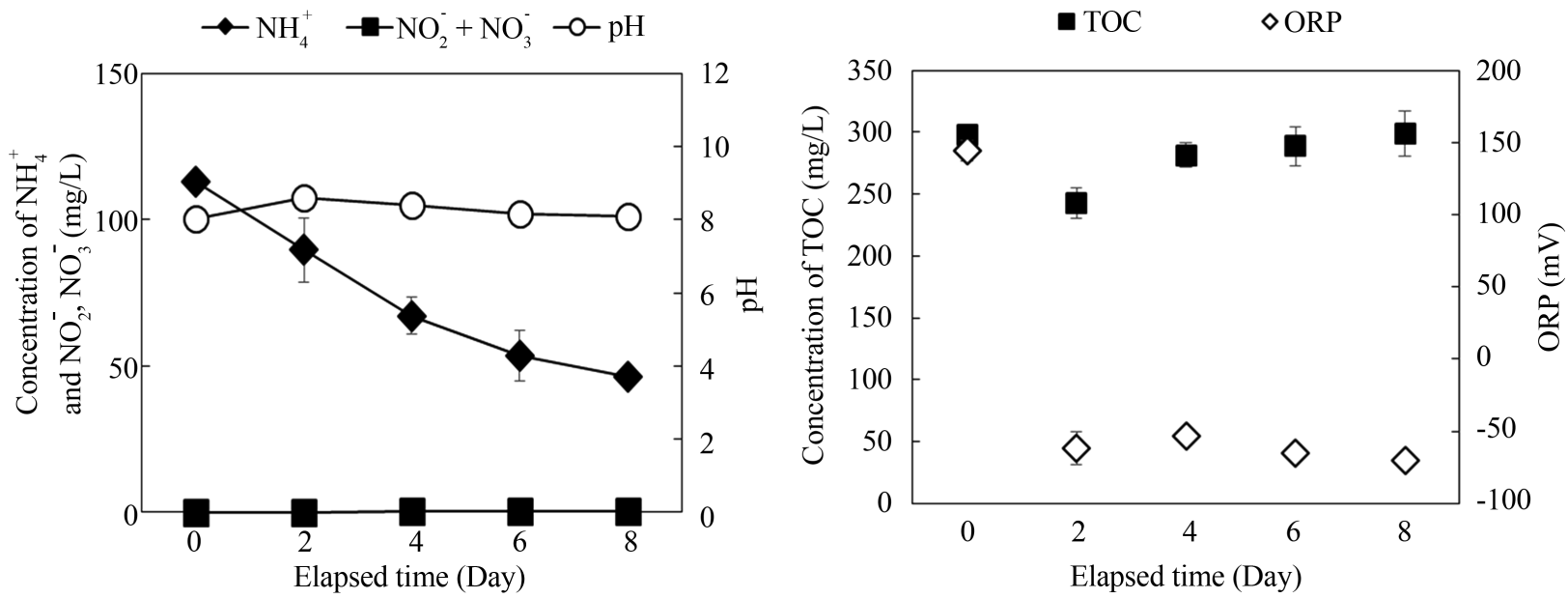

Figure 5. Results of batch treatment experiments left panel: nitrogen forms and concentrations over time. Right panel: total organic carbon (TOC) and oxidation reduction potential (ORP) over time. 


\subsection{Isolation of Microorganisms Grown in Synthetic Wastewater}

Table 4 shows the tentative identification of isolated microorganisms based on the color and shape of the isolated colonies. Table 5 shows the results of bacterial identification. Fragments of the $16 S \mathrm{r} R \mathrm{~A} A$ genes of $Y W_{-} 1-8, Y W_{-}$, and $Y_{-}$, which had different colony shapes and colors (Table 4) were amplified with sizes of $474 \mathrm{bp}, 552 \mathrm{bp}$, and $516 \mathrm{bp}$ for nucleotide sequence analysis. A BLAST search of these nucleotide sequences against the DNA Data Bank of Japan (DDB) showed 99\% homology of YW_1-8 with Lysinibacillus fusiformis strain P103, 99\% homology of YW_9 with Brevibacillus agri strain ST11, and 99\% homology of YC_9 with Cronobacter sakazakii strain BDCSS041 (Table 5). Lysinibacillus and Brevibacillus are aerobic Gram-positive rods and are closely related to Bacillus subtilis, suggesting that these bacteria were supported on biological charcoal. In particular, the Y_9 strain, which showed high homology with Cronobacter, had the highest $\mathrm{NH}_{4}^{+}$removal rate Therefore, it is likely that amino acids and proteins were synthesized in the Cronobacter sp. by assimilation of $\mathrm{NH}_{4}^{+}$. In previous reported examples, $\mathrm{NH}_{4}^{+}$treatment using nitrogen assimilation targeted $\mathrm{NH}_{4}^{+}$concentrations in compost of $0.001 \mathrm{mg} / \mathrm{L}$ to $50 \mathrm{mg} / \mathrm{L}$, and $\mathrm{NH}_{4}^{+}$concentrations in agricultural wastewater of $100 \mathrm{mg} / \mathrm{L}$ or more. There are few reports of this process and no studies on nitrogen assimilation by Cronobacter [22]. Cronobacter is a facultative anaerobe Gram-negative bacillus that is widely distributed in the intestinal tract of animals and in the natural environment; it is known to form biofilms.

Table 4. Colony morphology of strains isolated from synthetic wastewater and ammonium $\left(\mathrm{NH}_{4}^{+}\right.$) removal rate with an initial $\mathrm{NH}_{4}^{+}$concentration of $30 \mathrm{mg} / \mathrm{L}$.

\begin{tabular}{|c|c|c|c|}
\hline & Colony (color, morphology) & $\mathrm{NH}_{4}^{+}$ & removal rate (\%) \\
\hline$Y W_{-} 1-8$ & yellow-white, circle & & $11.3-28.4$ \\
\hline$Y W_{-} 9$ & yellow-white, irregular & & 39.5 \\
\hline$Y \_1-9$ & yellow, circle & & $83.8-96.5$ \\
\hline
\end{tabular}

Table 5. Identification of strains YW1-8, YW_9 and Y_9 strain by gram stain and BLAST search of $16 \mathrm{~S}$ rRNA gene sequences.

\begin{tabular}{cccc}
\hline & Closely related strains & Gram stain & $\begin{array}{c}\text { Homology } \\
\%)\end{array}$ \\
YW_1-8 & $\begin{array}{c}\text { Brevibacillus } \\
\text { spp. SWCRD_50 } \\
\text { YW_9 }\end{array}$ & $\begin{array}{c}\text { B. agi starain } \\
\text { MGH117 } \\
\text { Cronobactor sakazaki } \\
\text { strain NCTC8155 }\end{array}$ & 99 \\
Y_9 & strain BDSV12 & 99 & 99 \\
\hline
\end{tabular}




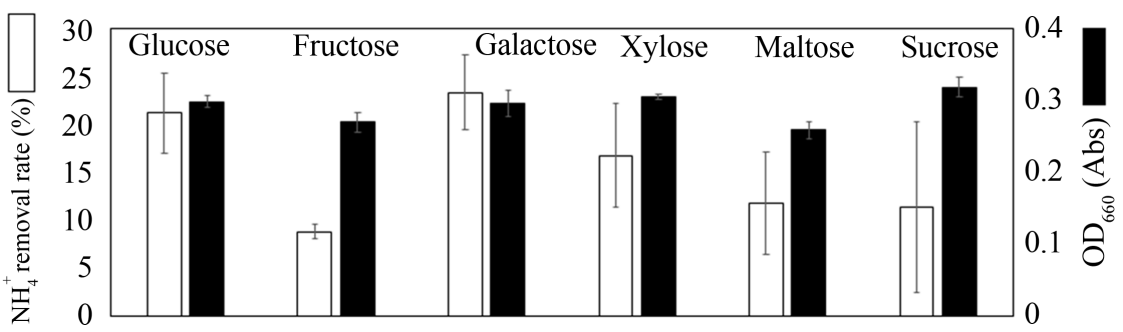

Figure 6. The effects of carbon source (carbohydrate) on ammonium removal and bacterial growth. Values presented are means \pm SD $(n=3)$.

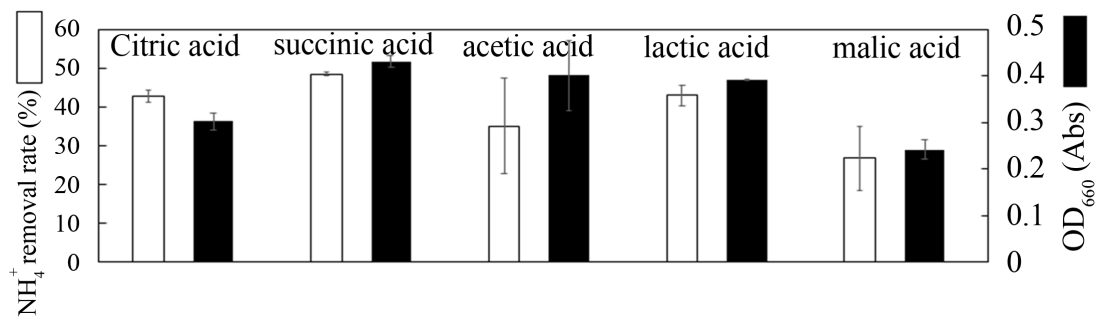

Figure 7. The effects of carbon source (organic acid) on ammonium removal and bacterial growth. Values presented are means $\pm \operatorname{SD}(n=3)$.

The Y_9 strain was confirmed as Gram-negative (Table 5) and showed high homology with the facultative anaerobe Cronobacter that was preferentially removed $\mathrm{NH}_{4}^{+}$in the synthetic wastewater. The nitrogen metabolism of microorganisms includes nitrate denitrification and nitrogen assimilation. During nitrogen assimilation, cells synthesize material from $\mathrm{NH}_{4}^{+}$and $\mathrm{NO}_{3}^{-} ; \mathrm{NO}_{2}^{-}$and $\mathrm{NO}_{3}^{-}$are not generated and $\mathrm{NH}_{4}^{+}$is removed from the environment. Therefore, it is likely that YW_9 and Y_9 absorbed $\mathrm{NH}_{4}^{+}$from the medium and used it for cellular growth and activity [23] [24].

The ability of Cronobacter to remove $\mathrm{NH}_{4}^{+}$was tested in media using different carbon sources at $1 \mathrm{~g} / \mathrm{L}$ (D-glucose, fructose, galactose, xylose, maltose and sucrose; Figure 6). In ammonium sulfate liquid medium containing $103 \pm$ $12 \mathrm{mg} \mathrm{NH} \mathrm{NH}_{4}^{+} / \mathrm{L}$, growth of Cronobacter on D-glucose or galactose resulted in decreases in the $\mathrm{NH}_{4}^{+}$concentration by 25.1 and $23.1 \mathrm{mg} / \mathrm{L}$, respectively. Growth of the strain increased through to stationary phase concentrations of $43 \times 10^{7}$ $\mathrm{CFU} / \mathrm{mL}$ or more.

The strain was also tested in liquid medium culture containing different organic acids (citric acid, succinic acid, acetic acid, lactic acid, and malic acid; Figure 7). The decrease in $\mathrm{NH}_{4}^{+}$concentration was higher during growth on organic acids than when compared with that during growth on sugars. The maximum $\mathrm{NH}_{4}^{+}$removal and cell growth were obtained during growth on succinic acid, but even during growth on acetic acid, the $\mathrm{NH}_{4}^{+}$removal was approximately 1.5 times that obtained during growth on glucose.

\section{Conclusions}

We investigated the denitrification of livestock wastewater containing $100 \% \mathrm{TN}$ 
in the form of ammonia by using biochar made from recycled pallets with embedded microorganisms. The $\mathrm{NH}_{4}^{+}$removal rate was $60 \%$ for both undiluted wastewater $(\mathrm{TOC} / \mathrm{TN}=0.27)$ and artificial wastewater $(\mathrm{TOC} / \mathrm{TN}=2.67)$ over 10 days. Pure cultures of microorganisms were isolated from the biofilm that formed on the charcoal surface. The isolates were identified as Lysinibacillus fusiformis strain P103, Brevibacillus agri strain ST11, and Cronobacter sakazakii strain BDCSS041. Cronobacter had the highest removal rate of $\mathrm{NH}_{4}^{+}$. The correlation between the $\mathrm{NH}_{4}^{+}$removal rate and OD660 suggested that nitrogen was fixed by assimilation. Because the nitrogen scavenging ability of Cronobacter was high, high growth and nitrogen removal were observed.

The growth and nitrogen removal were approximately 1.5 times higher when acetic acid was used as the carbon source rather than glucose. The results of this study suggest that Cronobacter shows potential for treating livestock waste liquid containing ammonium.

\section{Acknowledgements}

We thank Edanz (https://jp.edanz.com/ac) for editing a draft of this manuscript.

\section{Conflicts of Interest}

The authors declare no conflicts of interest regarding the publication of this paper.

\section{References}

[1] Waki, M., Yasuda, T., Fukumoto, Y., Kuroda, K., Sakai, T., Suzuki, N., Sizuki R., Matsubara, K. and Suzuki, K. (2010) Nitrogen Concentrations of Activated Sludge Process Effluent of Swine Wastewater. Journal of Japan Society on Water Environment, 33, 33-39. (Japanease) https://doi.org/10.2965/jswe.33.33

[2] Qing, H., Donde, O.O., Tian, C., Wang, C., Wu, X., Feng, S., Liu, Y. and Xiao, B. (2018) Novel Heterotrophic Nitrogen Removal and Assimilation Characteristic of the Newly Isolated Bacterium Pseudomonas stutzeri AD-1. Journal of Bioscience and Bioengineering, 126, 339-345. https://doi.org/10.1016/j.jbiosc.2018.03.010

[3] Zhang, L.-J., Xie, Y., Ding, L.-Y., Qiao, X.-J. and Tao, H.-C. (2020) Highly Efficient a Ammonium Removal through Nitrogen Assimilation by a Hydrogen-Oxidizing Bacterium, Ideonella sp. TH17. Environmental Research, 191, Article ID: 110059. https://doi.org/10.1016/j.envres.2020.110059

[4] Li, Y., Wang, Y., Fu, L., Gao, Y., Zhao, H. and Zhou, W. (2017) Aerobic-Heterotrophic Nitrogen Removal through Nitrate Reduction and Ammonium Assimilation by Marine Bacterium Vibrio sp. Y1-5. Bioresource Technology, 230, 103-111. https://doi.org/10.1016/j.biortech.2017.01.049

[5] Shi, Zh., Zhang, Y., Zhou, J., Chen Xiao, M. and Wang, J. (2013) Biological Removal of Nitrate and Ammonium under Aerobic Atmosphere by Paracoccus versutus LYM. Bioresource Technology, 148, 144-148. https://doi.org/10.1016/j.biortech.2013.08.052

[6] Qin, Y., Zhu, X., Su, Q., Anumah, A., Gao, B., Lyu, W., Zhou, X., Xing, Y. and Wang, B. (2020) Enhanced Removal of Ammonium from Water by Ball-Milled Biochar. Environmental Geochemistry and Health, 42, 1579-1587. 
https://doi.org/10.1007/s10653-019-00474-5

[7] Vu, T.M., Trinh, V.T., Doan, D.P., Van, H.T., Nguyen, T.V., Vigneswaran, S., et al. (2017) Removing Ammonium from Water Using Modified Corncon-Biochar. Science of the Total Environment, 579, 612-619. https://doi.org/10.1016/j.scitotenv.2016.11.050

[8] Wang, C., Ren, J., Qiao, X. and Habib, M. (2021) Ammonium Removal Efficiency of Biochar-Based Heterotrophic Nitrifying Bacteria Immobilization Body in Water Solution. Environmental Engineering Research, 26, Article No. 190451. https://doi.org/10.4491/eer.2019.451

[9] Gao, J., Zhu, T., Liu, C., Zhang, J., Gao, J., Zhang, J., Cai, M. and Li, Y. (2020) Ammonium Removal Characteristics of Heterotrophic Nitrifying Bacterium Pseudomonas Stutzeri GEP-01 with Potential for Treatment of Ammonium-Rich Wastewater. Bioprocess and Biosystems Engineering, 43, 959-969.

https://doi.org/10.1007/s00449-020-02292-x

[10] Liu, L., Gao, J., Huang, Z., Li, Y., Shang, N., Gao, J., Zhang, J. and Cai, M. (2021) Potential Application of a Pseudomonas geniculata ATCC 19374 and Bacillus Cereus EC3 Mixture in Livestock Wastewater Treatment. Waste and Biomass ValoriZation, 12, 3927-3938. https://doi.org/10.1007/s12649-020-01286-w

[11] Yu, Y., An, Q., Zhou, Y., Deng, S., Miao, Y., Zhao, B. and Yang, L. (2019) Highly Synergistic Effects on Ammonium Removal by the Co-System of Pseudomonas stutzeri XL-2 and Modified Walnut Shell Biochar. Bioresource Technology, 280, 239-246. https://doi.org/10.1016/j.biortech.2019.02.037

[12] Wang, X., Guo, Z., Hu, Z. and Zhang, J. (2020) Recent Advances in Biochar Application for Water and Wastewater Treatment: A Review. PeerJ, 8, Article No. e9164. https://doi.org/10.7717/peerj.9164

[13] Aoyama Eco System Co. (2021) Palette Recycle. https://www.aoyamaeco.co.jp/palette-recycle

[14] Tsuno, H., Nishimura, F. and Somiya, I. (1994) Removal of Ammonium Nitrogen in Bio-Zeolite Reactor. Transactions of Japanese Society of Irrigation, Drainage and Rural Engineering, 503, 159-166. https://doi.org/10.2208/jscej.1994.503_159

[15] Baird, R.B., Eaton, A.D. and Rice, E.W. (Eds,) (2017) Standard Methods for the Examination of Water and Wastewater. 23nd Edition, American Public Health Association, Washington DC.

[16] Ye, J., Coulouris, G., Zaretskaya, I., Cutcutache, I., Rozen, S. and Madden, T.L. (2012) Primer-BLAST: A Tool to Design Target-Specific Primers for Polymerase Chain Reaction. BMC Bioinformatics, 18, Article No. 134.

[17] U.S. National Library of Medicine National Center (n.d.) Basic Local Alignment Search Tool. https://blast.ncbi.nlm.nih.gov/Blast.cgi

[18] Sacchi, C.T., Whitney, A.M., Leonard, W.M., Morey, R., Steigerwalt, A., Boras, A., Weyant, R.S. and Popovic, T. (2002) Sequencing of 16S rRNA Gene: A Rapid Tool for Identification of Bacillus anthracis. Emerging Infectious Diseases, 8, 1118-11223. https://doi.org/10.3201/eid0810.020391

[19] Laboratory Stack (2021) Hucker's Modification Gram stain: Composition, Preparation and Procedure. https://universe84a.com/hucker-modification-gram-stain/

[20] Xiao, J., Zhu, C., Sun, D., Guo, P. and Tian, Y. (2011) Removal of Ammonium-N from Ammonium-Rich Sewage Using an Immobilized Bacillus subtilis AYC Bioreactor System. Journal of Environmental Sciences, 23, 1279-1285.

https://doi.org/10.1016/S1001-0742(10)60542-6 
[21] Sun, Y., Feng, L., Li, A., Zhang, X., Yang, J. and Fang, M.K. (2017) Ammo Nium Assimilation: An Important Accessory during Aerobic Denitrification of Pseudomonas stutzeri T13. Bioresource Technology, 234, 264-272. https://doi.org/10.1016/j.biortech.2017.03.053

[22] Keyser, M., Witthuhn, R.C., Ronquest, L.-C. and Britz, T.J. (2003) Treatment of Winery Effluent with Upflow Anaerobic Sludge Blanket (UASB)—Granular Sludges Enriched with Enterobacter sakazakii. Biotechnology Letters, 25, 1893-1898.

https://doi.org/10.1023/B:BILE.0000003978.72266.96

[23] Cueto-Rojas, H.F., Maleki Seifar, R., Ten Pierick, A., van Helmond, W., Pieterse, M.M., Heijnen, J.J. and Wahl, S.A. (2016) In Vivo Analysis of $\mathrm{NH}_{4}^{+}$Transport and Central N Metabolism of Saccharomyces cerevisiae under Aerobic N-Limited Conditions. Applied and Environmental Microbiology, 82, 6831-6845. https://doi.org/10.1128/AEM.01547-16

[24] Gunka, K. and Commichau, F.M. (2012) Control of Glutamate Homeostasis in Bacillus subtilis. A Complex Interplay between Ammonium Assimilation, Glutamate Biosynthesis and Degradation. Molecular Microbiology, 85, 213-224. https://doi.org/10.1111/j.1365-2958.2012.08105.x 